\title{
BOOK REVIEW
}

Tomlinson, P. B. 1986. The Botany of Mangroves. Cambridge University Press. ISBN 0-521-25567-8. Price: \$69.50. (Initiating a new series: the Cambridge Tropical Biology Series.)

Almost any botanist who has visited the tropics or subtropics will have encountered mangroves, and this refreshingly written book is the perfect introduction to both their taxonomy and biology. Overall, the book is a pleasing potpourri of selected data from many different fields about many different aspects of mangroves. The bulk of the book ( 211 pages) is a family-by-family summary of mangrove taxa, including original and very useful keys to the different species and genera of most of the mangrove families. Also included are discussions of various aspects of morphology, architecture, reproductive biology, and biogeography, as well as miscellaneous taxonomic notes and elegant illustrations of important species and genera. Although a key to "strict mangrove" genera is provided in the floristic section, no attempt is made to key out the different back-mangrove families. Thus the reader must first know the genus or family of the plant in which he is interested in order to take full advantage of Tomlinson's taxonomic section. Nevertheless, from the viewpoint of the systematic botanist, the gathering together in one place of the available nomenclatural and taxonomic data for mangrove species and genera is a high point of the book, as are the author's personal observations on identification and biology of the individual species.

Throughout, but especially in the photo captions, the author's puckish sense of humor often comes to the fore. A Nypa stem is aptly described as "resembling nothing so much as a series of overlapping cowplats." The fruits of Avicennia alba are said "to resemble a gorged leech." An "obliging butterfly visitor" in a photo of Lumnitzera racemosa is contrasted with lack of an obliging bird visitor in $L$. littorea.

Another strong point of the book, as might be expected considering the author's research predilection, is the series of chapters devoted to the fascinating morphological and anatomical specializations of mangroves. No fewer than four chapters and 71 pages treat shoot systems, root systems, water relations and salt balance, and seedlings and seeds. In contrast, the five chapters devoted to ecology, floristics, biogeography, flowering, and utilization and exploitation amount to only 68 pages.

I found the treatment of mangrove ecology disappointing. The author acknowledges this deficiency and justifies it by noting that ecology is generally outside his area of expertise. However, a tremendous amount of effort has been devoted to this field, and a few extra pages devoted to mangrove zonation and summarizing some of the abundant and often conflicting literature that implicates different toleration of salt concentrations vs. soil texture and edaphic conditions vs. rainfall would have been a welcome addition, especially if accompanied by the author's own trenchant evaluations.

A minor but bothersome ecological problem is Dr. Tomlinson's adoption of the word "mangal" to refer to the mangrove community while "mangrove" is reserved for the constituent plants. I find this to serve no useful purpose and to be distinctly cumbersome in the same way as the plethora of Braun-Blanquet classificatory endings. Luckily, after emphasizing "mangal" in the first chapter, the author himself largely abandons it in later chapters where traditional terms like "mangroves," "mangrove associates," and "mangrove communities" are often used instead. In this review I will use exclusively the traditional terms in hopes that "mangal" (as well as Rhizophoretum, etc.) will soon pass into welldeserved oblivion.

Another, more significant, ecological problem is the author's attempt to separate mangrove species into "strict mangroves" (subdivided as to major and minor components) and "mangrove associates." While this should be quite a natural way to divide mangrove taxa, in my opinion many taxa are wrongly placed in the tables on pages $27-30$, and others, even those treated elsewhere in the book, are outright omitted. This is especially obvious for the PacificAmerican mangrove taxa, and inclusion of some of the omitted full-mangrove species would give rise to very different conclusions. For example, the taxonomic distinctiveness of strict mangrove species is far more often at the level of species than Tomlinson implies. Glaring outright omissions from these lists include Tabebuia palustris and Phryganocydia phellosperma, which are strict mangroves, not even "back-mangroves"; indeed 
in the case of Bignoniaceae the back mangroves are correctly listed but the full mangroves are completely ignored! Crenea patentinervis, mentioned as a potential herbaceous mangrove in the text, is not included in any of the tables of mangroves or mangrove associates on the grounds that as an herb it cannot be a true mangrove. Actually Crenea is a subshrub and is at least as woody as such included genera as Acrostichum, Tuberostylis, Acanthus, or Batis. Even were it an herb, that would be no reason to exclude it, especially as it is a full-mangrove species, not a back-mangrove. Both species of Tuberostylis are mangroves and they are mostly epiphytic on the roots and lower trunks of full-mangroves rather than on back-mangroves. Some major mangrove components are relegated to the "minor" list, e.g., Pelliciera which forms pure mangrove forests many $\mathrm{km}^{2}$ in extent in the delta of the Río San Juan in Colombia. Gymnosperms are specifically mentioned as playing no role in mangroves even though Zamia roezli is typically found in mangroves and is restricted to them and to the adjacent coastal fringe. Muellera (p. 263) is stated to be most commonly recorded well away from the sea, but I have seen it only in the back-mangrove regions with a distinct tidal influence and strongly suspect that the entire genus is restricted to this habitat.

There are also serious problems with the numbers of species given for mangrove genera, especially since the data in these tables are used as evidence of the taxonomic distinctiveness of mangrove plants. Thus the single back-mangrove species of Amphitecna is not the only species of this 18-species genus, and Hippomane has four noncoastal species as well as the well-known coastal one. Mangrove epiphytes are implied to be basically plants from nearby terrestrial communities that transgress into the mangroves. Yet many epiphytes seem unique to mangroves (such as the entire genus Tuberostylis) and others are certainly more characteristic of mangroves than other habitats. Similarly, Tomlinson states that there are no climbers in mangroves, presumably because climbers have wide vessels subject to extreme water tension, yet there is at least one clear exception. Phryganocydia phellosperma is not a species that roots behind the mangroves and scrambles into them (although its unlisted confamilial Cydista aequinoctialis is and should probably be added to the list of mangrove associates); it is a strict mangrove and roots in (and only in) the mangroves themselves.
The biogeographic discussion focuses so much on the dichotomy between the relatively depauperate western mangroves vs. the more diverse eastern ones that the almost equally striking difference between the richer mangrove flora of the Pacific Coast of South America as compared with the Atlantic one (possibly related to the relatively recent opening of the Atlantic Ocean?) is overlooked. Only eight true mangroves are said to occur in the western hemisphere, although a local concentration of "incipient mangroves" in western Colombia is acknowledged. While these species are said to be mere mangrove associates that "lack complete fidelity to mangal" (p. 55), several of them are true and obligate mangroves in the strictest sense (although there are also endemic back-mangrove species in this region). It may well be that the western Colombian mangroves are fundamentally different from other mangroves in their greater habit diversity and in being mostly individual mangrove species of otherwise nonmangrove genera, but they are not less true mangroves for that. Knowledge of mangroves would be better served by focusing on the unusual aspects of these species rather than by trying to sweep them under the rug.

There are a number of inconsistencies, especially in the biogeographic discussions. Rhizophora racemosa is on both Atlantic and Pacific sides of tropical America as reported on p. 334, but in the key (p. 329) it is characterized as being only on the Atlantic coast of South America. There are five Pacific coast collections in the MO herbarium, as well as collections from Honduras, Costa Rica, and Panama, all outside the Venezuela and Guianas to West Africa range indicated by Tomlinson (p. 335). Rhizophora harrisonii is rather precisely mapped as having a disjunct population in the middle of the Peruvian coastal desert outside the range of any mangrove, but the numerous records from coastal Ecuador and Colombia were apparently overlooked. On the other hand, the range of $R$. samoensis is hypothetically extended to include the Pacific coast of South America, where it may occur but has not yet been documented; that species does reach the Galapagos, according to R. Horna (pers. comm.).

Inevitably a few insignificant errors in spelling of Latin binomials, taxonomic authorities, etc. are unavoidable in a book of this scope. Examples include "Anaemopegma" (p. 32), "Mouriria" and "Pachyra" (p. 56) and the authors of both species of Phryganocydia (p. 214). More 
problematic is Lysianthus (presumably $=$ Lysiana?) supposed to be a mangrove mistletoe (p. 33). Dalbergia amerimnion Benth. (p. 261) has long been regarded as a synonym of $D$. brownei. Phryganocydia phellosperma is not distinguished from $P$. corymbosa by a simple tendril, a trait shared with the entire genus. Tabebuia palustris is not deciduous as stated (p. 214), which would have been quite remarkable in a mangrove, but evergreen like all other mangroves known to me.

Similar minor errors in biogeographic distributions include Tuberostylis rhizophorae, whose claimed "wider distribution in Central America" consists of a single collection from southernmost Darién, and Pavonia rhizophorae, supposed to be recorded only for Colombia but reported in the Flora of Panama to cross the Panama border in the same part of southern Darién.

Obviously, it is difficult to eliminate such miscellaneous errors. Whether they are as frequent in other taxa and regions as among the mangroves I happen to know personally (i.e., mostly Bignoniaceae and Pacific American), I do not know. But it seems likely that it would have been useful for the author to run a draft of his manuscript past a few taxonomic specialists or field botanists as well as checking a few more herbaria for distributional data. Such minor imperfections detract very little from the message of the book, except that inasmuch as this is the closest thing to a monograph of many mangrove taxa that we are likely to have in the foreseeable future, it is a bit of a shame that some of the work that would have gone into an actual monograph was neglected. Overall The Botany of Mangroves succeeds admirably in its purpose of providing a concise and highly readable introduction to the world's mangroves.-Alwyn Gentry, Missouri Botanical Garden, P.O. Box 299, St. Louis, Missouri 63166 , U.S.A. 


\section{$2 \mathrm{BHL}$ Biodiversity Heritage Library}

Gentry, Alwyn H. and Tomlinson, P. B. 1987. "The Botany of Mangroves." Annals of the Missouri Botanical Garden 74, 460-462.

https://doi.org/10.2307/2399427.

View This Item Online: $\underline{\text { https://www.biodiversitylibrary.org/item/87376 }}$

DOI: https://doi.org/10.2307/2399427

Permalink: $\underline{\text { https://www.biodiversitylibrary.org/partpdf/19325 }}$

\section{Holding Institution}

Missouri Botanical Garden, Peter H. Raven Library

\section{Sponsored by}

Missouri Botanical Garden

\section{Copyright \& Reuse}

Copyright Status: In copyright. Digitized with the permission of the rights holder.

License: http://creativecommons.org/licenses/by-nc-sa/3.0/

Rights: https://biodiversitylibrary.org/permissions

This document was created from content at the Biodiversity Heritage Library, the world's largest open access digital library for biodiversity literature and archives. Visit BHL at https://www.biodiversitylibrary.org. 